\title{
RANCANG BANGUN PROTOTIPE DETEKTOR HUJAN SEDERHANA BERBASIS RAINDROP SENSOR MENGGUNAKAN BUZZER DAN LED
}

\author{
Naila Fauza*, Dina Syaflita, Safina Salma Ramadini, Jumira Annisa, Fitri Armala, Exsy \\ Martinqa, Eka Dewi Susanti, Vivia Melannia
}

Program Studi Pendidikan Fisika, Universitas Riau, Jalan Bina Widya Km12.5, Panam, Pekanbaru e-mail*: naila.fauza@gmail.com

\begin{tabular}{c|c|c}
\hline Diterima 26 Juli 2021 & Disetujui 17 November 2021 & Dipublikasikan 31 Desember 2021 \\
\hline \multicolumn{3}{c}{ https://doi.org/10.33369/jkf.4.3.163-168 } \\
\hline
\end{tabular}

\begin{abstract}
ABSTRAK
Indonesia adalah negara dengan iklim tropis yang memiliki dua musim yaitu musim hujan dan musim kemarau dimana kedua musim ini sulit untuk diprediksi kedatangannya. Penelitian ini bertujuan untuk merancang dan membuat alat pendeteksi hujan sederhana berbasis raindrop sensor menggunakan buzzer dan LED. Rancang bangun prototipe detektor hujan sederhana ini dilengkapi dengan raindrop sensor sebagai sensor hujan serta buzzer dan LED sebagai outputnya. Penelitian ini menggunakan metode penelitian Research and Development. Adapun tahap pengembangan dalam penelitian ini meliputi perencanaan, produksi, dan evaluasi. Alat detektor hujan ini terdiri atas komponenkomponen elektronika, yaitu raindrop sensor, buzzer, LED, transistor dan sakelar. Selanjutnya, dilakukan pengujian alat secara keseluruhan untuk melihat apakah alat berfungsi sesuai dengan tujuan. Dari hasil pengujian yang dilakukan membuktikan alat yang dibuat dapat berfungsi dengan baik. Ketika hujan, sensor hujan bekerja maka buzzer akan mengeluarkan suara dan LED-nya menyala. Dari hasil pengujian menunjukkan intensitas bunyi pada buzzer yang berbeda-beda tergantung dari tingkat kelembaban PCB-nya, hal ini dapat disimpulkan bahwa semakin basah PCB nya, semakin besar pula intensitas bunyi pada buzzer-nya.
\end{abstract}

Kata kunci : Detektor Hujan, Buzzer, LED, Sensor Hujan

\begin{abstract}
Indonesia is a country with a tropical climate that has two seasons, namely the rainy season and the dry season where both seasons are difficult to predict. This research aims to design and manufacture a simple rain detector based on a raindrop sensor using a buzzer and LED. The design of this simple rain detector prototype is equipped with a raindrop sensor as a rain sensor as well as a buzzer and LED as its output. This research uses Research and Development research methods. The development stages in this research include planning, production, and evaluation. This rain detector consists of electronic components, namely raindrop sensors, buzzers, LEDs, transistors and switches. Furthermore, the overall tool testing is carried out to see if the tool functions according to its purpose. From the results of the tests carried out, it proves that the tool made can function properly. When it rains, the rain sensor works, the buzzer will make a sound and the LED will light up. The test results show that the intensity of the sound on the buzzer varies depending on the humidity level of the PCB, it can be concluded that the wetter the PCB, the greater the intensity of the sound on the buzzer.
\end{abstract}

Keywords : Rain Detector, Buzzer, LED, Raindrop Sensor

\section{PENDAHULUAN}

Indonesia adalah negara yang beriklim tropis dengan dua musim yaitu musim hujan dan musim kemarau. Kedua musim ini dipengaruhi oleh Global Warming yang mengakibatkan kedua musim tersebut menjadi lebih sulit untuk diprediksi kedatangannya(1). Hal itu tentunya akan berpengaruh pada aktivitas masyarakat yang dalam kegiatannya membutuhkan cahaya matahari, misalnya kegiatan menjemur baju, makanan atau barang lainnya di luar ruangan. Pada program studi pendidikan fisika, terdapat mata kuliah elektronika praktis. Melalui mata kuliah 
ini, mahasiswa akan mengetahui piranti-piranti elektronika dan alat apa saja yang dapat dibuat dengan menggunakan piranti elektronika tersebut beserta manfaatnya. Salah satunya yaitu alat yang dapat mendeteksi hujan sehingga dapat mengurangi kekhawatiran akan datangnya hujan secara tiba-tiba.

Penelitiannya sebelumnya alarm pendeteksi hujan dikembangkan untuk mengurangi tingkat kecerobohan manusia terhadap datangnya hujan. Alat ini menggunakan alumunium foil sebagai water sensor (sensor air) dan IC NE555 sebagai penghasil frekuensi pada rangkaian tersebut. Frekuensi yang dihasilkan bergantung pada besarnya nilai resistor yang berhubungan langsung dengan IC. Oleh karena itu, percikan air yang mengenai alumunium foil menyebabkan bunyi dan LED menyala (2). Jika resistor tidak sesuai menyebabkan IC menjadi panas dan rusak. Alat ini menggunakan rangkaian IC NE555 sebagai pembangkit frekuensinya sehingga kurang efisien dalam merangkai dan aplikasinya(3).

Detektor hujan juga pernah diimplementasikan sebelumnya, yaitu sebuah sistem monitoring pendeteksian hujan dan suhu berbasis sensor secara real-time, dengan mengaplikasikan telemetri sebagai media komunikasi data jarak jauh. Real time clock (RTC) merupakan sebuah alat yang dilengkapi pembangkit waktu dan baterai dimana memungkinkan untuk menghasilkan waktu yang tepat(4). Dari hasil percobaan, pengamatan dan analisis yang telah dilakukan, sistem dapat melakukan fungsi pemantauan secara real-time. Sensor curah hujan dapat digunakan untuk mendeteksi curah hujan, dan perbedaan rata-rata antara pembacaan sensor suhu dan termometer adalah sekitar $0,39^{\circ} \mathrm{C}$, sehingga alat yang dibangun dapat digunakan sebagai sistem yang dapat memberikan informasi pendeteksian curah hujan dan pengukuran suhu secara real-time melalui komunikasi nirkabel(5).

Dalam penelitiannya yang lain juga telah dibuat detektor hujan otomatis menggunakan modul GSM berbasis mikrokontroler ATMega328p dengan tujuan untuk mendeteksi terjadinya hujan di lokasi pemasangan alat. Pada penelitian ini menggunakan piranti yang meliputi arduino uno sebagai pengendali, relay sebagai pengendali motor DC, Liquid Cristal Display (LCD), sensor hujan sebagai pendeteksi air, sensor cahaya sebagai pendeteksi cahaya, motor DC sebagai output untuk membuka dan menutup atap, serta buzzer sebagai output berupa suara. Hasil penelitian ini membuktikan bahwa alat yang dibuat dapat berfungsi baik yaitu ketika mendung maka sistem akan mengirimkan SMS sebagai perintah untuk menutup atap, dan ketika hujan atap secara otomatis menutup tanpa harus ada perintah(6). Dari segi manfaat tentunya alat tersebut dapat memberikan fungsi yang lebih baik karena pada pada alat ini dilengkapi dengan sensor hujan dan sensor cahaya serta arduino uno sebagai pengendali. Namun dari segi perancangan alat, alat ini cukup sulit untuk orang-orang yang tidak mahir khususnya di bidang elektronika, serta membutuhkan alat seperti laptop, LCD dan motor DC yang mungkin harganya cukup mahal bagi sebagian orang. Berdasarkan permasalahan tersebut peneliti merancang alat sederhana yang dapat menginformasikan cuaca hujan yang sedang terjadi di lokasi tempat penjemuran tersebut. Alat tersebut disebut sebagai alat pendeteksi hujan atau alat detektor hujan. Berbeda dari penelitian sebelumnya, rangkaian detektor hujan ini mempunyai indikator yaitu buzzer dan LED.

Buzzer merupakan perangkat elektronika yang dapat mengubah getaran listrik menjadi getaran suara. Cara kerja perangkat elektronika ini hampir mirip dengan loudspeaker(7). LED atau singkatan dari Light Emitting Diode, yaitu sejenis lampu indikator pada peralatan elektronika yang berfungsi untuk menunjukkan keadaan peralatan elektronik(8). LED adalah salah satu dioda yang terbuat dari bahan semikonduktor, terdiri dari chip semikonduktor yang didoping, yang dapat menghasilkan sambungan $\mathrm{P}$ dan $\mathrm{N}$ dan dapat memancarkan cahaya monokromatik ketika dibias maju(9). Rangkaian detektor hujan ini sangat sederhana dan dibangun menggunakan komponen utama yaitu sensor hujan atau raindrop sensor,

Raindrop sensor atau sensor hujan adalah sebuah alat yang dapat mendeteksi ada tidaknya hujan di sekitar alat sehingga sensor akan aktif jika terkena air hujan(10). Selain dirancang untuk mendeteksi air hujan, sensor ini juga dapat digunakan untuk mendeteksi level air dan lainlain(11). Sensor hujan merupakan sensor yang peka terhadap air hujan yang digunakan untuk 
memberikan nilai input pada tingkat elektrolisis air hujan. Sensor hujan pada rangkaian pendeteksi hujan dapat dibuat dari PCB, kemudian didesain sedemikian rupa sehingga memenuhi prinsip sambungan antara kedua terminal saat terkena hujan(12). Sebagai indikator bahwa sensor hujan mendeteksi hujan, rangkaian akan memberikan sinyal keluaran berupa suara buzzer dan nyala LED.

Prinsip kerja pada alat ini adalah ketika detektor hujan yang sudah dirangkai dan dihubungkan ke baterai dan saklar pada posisi ON maka sensor akan mendeteksi hujan dengan membunyikan buzzer dan menyalakan LED ketika sensor terkena percikan air. Melalui alat ini, harapannya, alat detektor hujan menggunakan buzzer dan LED ini dapat membantu dalam mendeteksi hujan yang terjadi sehingga memudahkan dalam mengantisipasi basahnya benda yang dijemur.

\section{METODE PENELITIAN}

Jenis penelitian ini adalah penelitian penemuan dan pengembangan (research and development). Penelitian pengembangan adalah sebuah proses yang digunakan untuk mengembangkan dan memvalidasi suatu produk pendidikan(13). Metode penelitian R\&D adalah metode penelitian yang digunakan untuk menghasilkan produk baru, menguji keefektifan produk yang sudah ada, serta mengembangkan dan menciptakan produk baru(14). Ada tiga langkah penelitian dan pengembangan, dimulai dari tahap perencanaan (planning), kemudian tahap produksi (production) dan terakhir evaluasi (evaluation)(15).
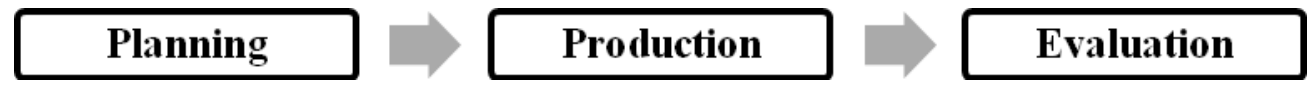

\section{Gambar 1. Tahapan Penelitian}

Tahap perencanaan merupakan tahap perencanaan pada alat-alat yang digunakan dalam penelitian yang dilakukan. Ada dua langkah dalam tahap perencanaan, yaitu analisis kebutuhan dan desain atau perancangan. Langkah analisis kebutuhan dilakukan dengan mempelajari literaturliteratur pada buku-buku atau jurnal-jurnal penelitian sebelumnya yang terkait untuk mendapatkan komponen-komponen alat yang dibutuhkan untuk perancangan(16). Berdasarkan analisis kebutuhan tersebut, maka komponen alat yang digunakan yaitu raindrop sensor, buzzer, LED, transistor BC547, sakelar, baterai, solder dan timah.

Selanjutnya adalah tahap produksi, pada tahap ini produk akan diproduksi sesuai dengan rancangan yang sudah dibuat. Produk yang dirancang dalam penelitian ini adalah alat pendeteksi hujan sederhana yang berbasis raindrop sensor menggunakan buzzer dan LED. Terakhir adalah tahap evaluasi ini dilakukan kegiatan pengujian produk untuk mengevaluasi apakah produk dapat berfungsi dengan baik sesuai dengan tujuan yang telah ditentukan. Pada penelitian ini tahap evaluasi dilakukan melalui pengujian produk secara keseluruhan. Penelitian dilaksanakan di Laboratorium Pendidikan Fisika, Jurusan PMIPA FKIP Universitas Riau, Pekanbaru pada bulan Mei-Juli.

\section{HASIL DAN PEMBAHASAN \\ 3.1 Planning (Perencanaan)}

Dalam tahap perencanaan ini, terlebih dahulu melakukan analisis kebutuhan melalui studi literatur atau pengumpulan informasi terkait penelitian yang relevan. Dalam pengembangan alat pendeteksi hujan ini mengacu pada beberapa penelitian sebelumnya yaitu Nurliwati dkk (2019) dengan judul "Rancang Bangun aplikasi andriod pengngat jemuran pakaian berdasarkan cuaca untuk wilayah Semarang" dan Handaru, Afroni dan Basuki (2019) dalam penelitiannya yang berjudul "Rancang Bangun Alat Pendeteksi Hujan Otomatis Menggunakan Modul GSM Berbasis Mikrokontroler ATMega 328p". Berdasarkan studi literatur pada penelitian yang relevan tersebut, diperoleh komponen apa saja yang dibutuhkan serta rancangan dari produk yang dikembangkan. Selanjutnya dilakukan perancangan yang diawali dengan merancang diagram blok terlebih dahulu. 
Adapun diagram blok dari rancang bangun alat detektor hujan dapat dilihat pada Gambar 2.

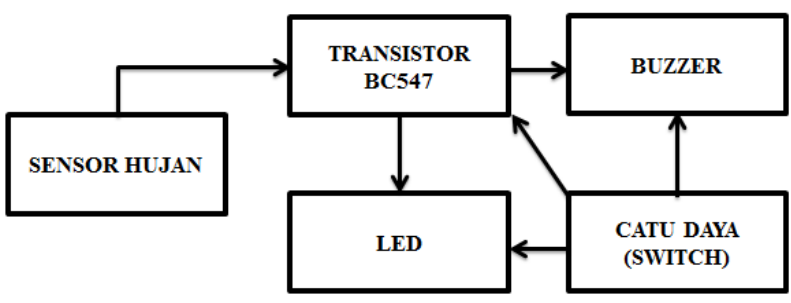

Gambar 2. Diagram Blok Alat

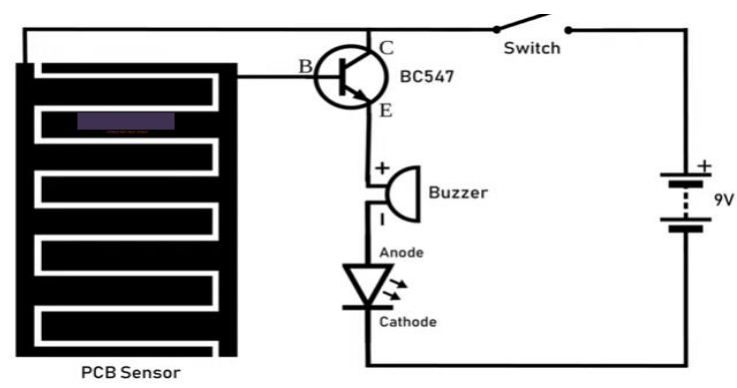

Gambar 3. Perancangan Alat

Gambar 2 adalah skema perancangan alat dari beberapa piranti elektronik yang digabungkan menjadi satu rangkaian menyeluruh. Seperti yang ditunjukkan pada Gambar 2 bahwa PCB sensor sebagai komponen utama pada alat dan buzzer serta LED sebagai output dari alat dimana buzzer akan mengeluarkan suara seperti alarm ketika terdeteksi hujan

\subsection{Production (Produksi)}

Pada tahap ini produk telah dibuat sesuai dengan rancangan yang sudah dibuat sebelumnya. Kegiatan produksi ini dilakukan untuk menghasilkan alat yang dapat digunakan untuk mendeteksi hujan. Sebelum membuat alat, setiap komponen elektronik yang digunakan (seperti LED, buzzer, dan transistor) telah diuji. Hal ini dilakukan untuk memastikan alat yang digunakan dalam kondisi baik dan dapat bekerja sesuai fungsinya.

Setelah dilakukan pengujian pada tiap komponen, selanjutnya dilakukan penggabungan semua komponen untuk menghasilkan alat yang dapat mendeteksi hujan. Pertama seluruh komponen di rangkai sesuai skema menggunakan timah dan solder yang mana hasilnya dapat dilihat pada Gambar 4. Selanjutnya komponen yang sudah dirangkai menjadi satu rangkaian tersebut dimasukkan dan disusun sedemikian rupa pada rumah stik eskrim agar lebih tahan air dan tampilannya lebih menarik seperti pada Gambar 5.

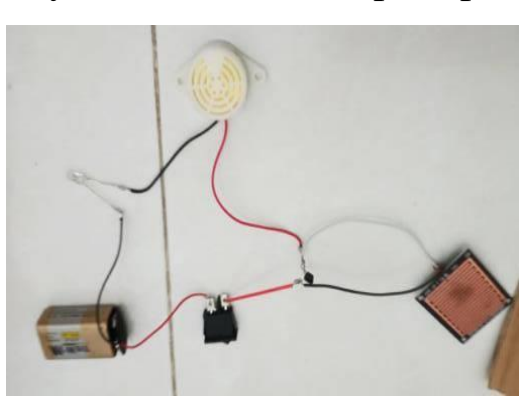

Gambar 4. Rangkaian Detektor Hujan

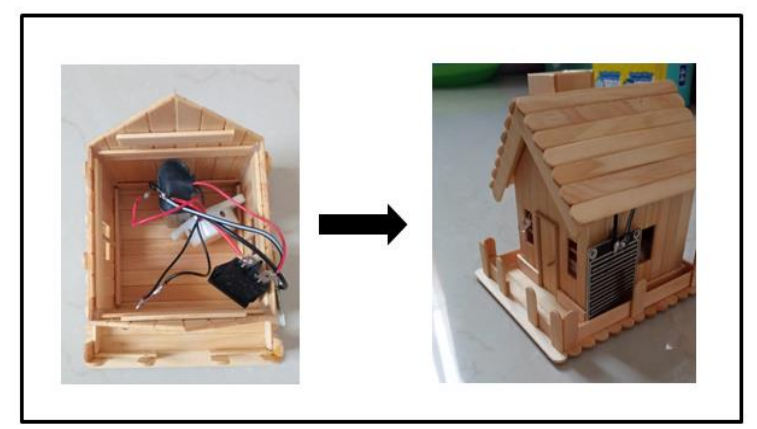

Gambar 5. Alat Detektor Hujan Secara Keseluruhan

\subsection{Evaluation (Evaluasi)}

Pada tahap evaluasi ini sudah dilakukan pengujian alat detektor hujan. Alat berfungsi dengan baik ketika indikator buzzer berbunyi dan LED menyala. Dalam pengujian alat detektor hujan ini digunakan botol semprot sebagai hujan buatannya. Adapun hasil pengujian alat secara keseluruhan dapat dilihat pada Tabel 1. 
Tabel 1. Pengujian Alat Detektor Hujan

\begin{tabular}{cccc}
\hline \multirow{2}{*}{ Jumlah Spray } & \multirow{2}{*}{ Keadaan PCB } & \multicolumn{2}{c}{ Indikator } \\
\cline { 3 - 4 } & & Buzzer & LED \\
\hline 1 Kali & Bering & Tidak Berbunyi & Mati \\
2 Kali & Basah & Berbunyi Pelan & Nyala \\
3 Kali & Basah & Berbunyi Nyaring & Nyala \\
4 Kali & Basah & Berbunyi Nyaring & Nyala \\
- & Lembab & Berbunyi Sangat Pelan & Nyala \\
& & & \\
\hline
\end{tabular}

Berdasarkan tabel 1, pengujian alat dilakukan dengan menggunakan tegangan +9 Volt. Pada pengujian pertama, ketika sakelar pada posisi ON dan tidak disemprotkan air maka buzzer tidak berbunyi dan LED tidak menyala. Pada pengujian kedua, ketika sakelar pada posisi ON dan PCB disemprot air satu kali yang terjadi adalah buzzer mengeluarkan suara tetapi pelan dan indikator LED-nya menyala. Selanjutnya pada pengujian ketiga hingga kelima, ketika sakelar pada posisi ON dan PCB sensor disemprotkan masing-masing dua kali, tiga kali dan empat kali maka yang terjadi adalah buzzer mengeluarkan bunyi yang semakin nyaring dan indikator LED tetap menyala. Pada pengujian terakhir, ketika sakelar dibiarkan pada posisi ON tanpa disemprotkan air pada PCB dan dibiarkan hingga kering maka buzzer tetap berbunyi tetapi semakin lama semakin pelan sampai tidak berbunyi lagi. Ini menunjukkan bahwa raindrop sensor memiliki tingkat kepekaan terhadap air yang cukup tinggi, terbukti dari buzzer yang tetap mengeluarkan bunyi ketika sensor dalam keadaan lembab. Berikut gambar uji coba alat detektor hujan yang ditunjukkan pada Gambar 6.

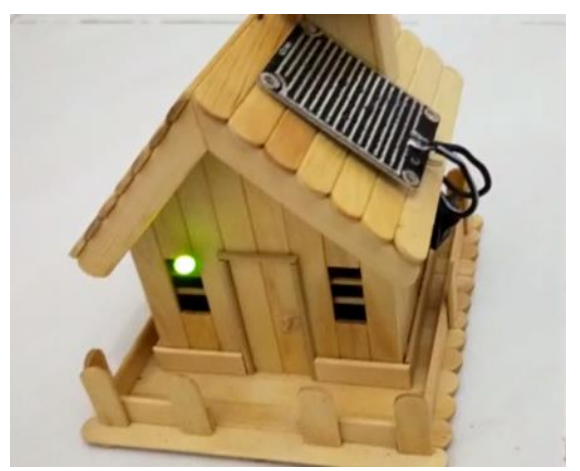

Gambar 6. Pengujian Alat Detektor Hujan

Dari hasil pengujian yang telah dilakukan, dapat dijelaskan bahwa alat detektor hujan berbasis raindrop sensor menggunakan buzzer dan LED ini dapat berfungsi sesuai dengan yang direncanakan. Setiap piranti-piranti elektronika baik sensor hujan, buzzer, LED dan transistor dapat berfungsi dengan baik. Hal ini dibuktikan dari output alat yang dapat berfungsi dengan baik sesuai keadaan yang ditentukan.

Hasil penelitian tersebut sejalan dengan penelitian sebelumnya, yakni "Rancang Bangun Alat Pendeteksi Hujan Otomatis Menggunakan Modul GSM Berbasis Mikrokontroler ATMega 328p" yang menggunakan komponen-komponen elektronika berupa arduino uno sebagai pengendali, relay sebagai pengendali motor DC, sensor hujan, sensor cahaya dan motor DC sebagai output untuk membuka dan menutup atap, serta buzzer sebagai output suara. Hasil penelitian ini menyatakan bahwa jika nilai digital dari sensor hujan < 900 maka buzzer dan Motor DC HIGH (ON) dengan durasi 5.0 detik atau tertutup, dan jika tidak hujan > 900 maka tidak akan bereaksi apapun. Sedangkan, jika nilai digital dari sensor cahaya > 900 maka buzzer dan Motor DC HIGH (ON) dengan durasi 5.0 detik atau atap terbuka(6).

\section{SIMPULAN DAN SARAN}

\subsection{Simpulan}

Setelah dilakukan perancangan, pengamatan dan pengujian pada alat pendeteksi hujan berbasis 
raindrop sensor menggunakan buzzer dan LED, dapat dilihat bahwa alat dan setiap rangkaian berfungsi dengan baik sesuai dengan yang dirancang. Dari hasil pengujian menunjukkan intensitas bunyi pada buzzer yang berbeda-beda tergantung dari tingkat kelembaban PCB-nya, hal ini dapat disimpulkan bahwa semakin basah PCB nya, semakin besar pula intensitas bunyi pada buzzer-nya.

\subsection{Saran}

Untuk pengembangan alat ini lebih lanjut, saran yang diberikan adalah agar alat ini dapat dilengkapi dengan alat ukur tegangan sensor dan alat ukur curah hujan sehingga dapat diketahui secara pasti pada curah hujan berapa persen buzzer dapat aktif mengeluarkan bunyi.

\section{UCAPAN TERIMA KASIH}

Terimakasih kepada koordinator Pendidikan Fisika FKIP Universitas Riau yang telah memfasilitasi penelitian. Selanjutnya, kepada pihak terkait yang membantu pembuatan alat.

\section{DAFTAR PUSTAKA}

1. Siswanto D, Winardi S. Jemuran Pakaian Otomatis Menggunakan Sensor Hujan. Narodroid. 2015;1(2):66-73.

2. Lubis, M. Fhad. TF. Studi Pembuatan Alarm Pendeteksi Hujan (Alarm Hujan). Universitas Gunadarma. Depok; 2006.

3. Rukmana STE, Mayub A, Medriati R. Prototype Alat Pendeteksi Dan Pengusir Tikus Pada Pembibitan Kelapa Sawit Berbasis Arduino Uno. J Kumparan Fis. 2019;2(1):9-16.

4. Kadir A. From Zero to a Pro Arduino. Yogyakarta: Penerbit ANDI; 2015.

5. Muhamad Yusvin Mustar ROW. Implementasi Sistem Monitoring Deteksi Hujan dan Suhu Berbasis Sensor Secara Real Time (Implementation of Rain Detection and Temperature Monitoring System Based on Real Time Sensor). Vol. 20, Semesta Teknika. 2017.

6. Handaru, A. A., Afroni, M. J., Basuki BM. Rancang Bangun Alat Pendeteksi Hujan Otomatis Menggunakan Modul GSM Berbasis Mikrokontroler ATMega 328p. 2019;25-30.

7. Purnamasari W dan RW. Sistem Keamanan Rumah Menggunakan Sensor Getaran Dengan Output Suara Berbasis Pc. J Manaj dan Inform Pelita Nusant. 2017;21(1):59.

8. Mutmainnah M, Rofii I, et al. Karakteristik Listrik dan Optik pada LED dan Laser. J Teor dan Apl Fis. 2020;8(2):203-8.

9. Ahmad Ruslan Abdul A, Yushardi R. Penggunaan Dioda Jenis LED (Light Emiting Diode) Pada Pembuatan Sel Surya Sederhana Berbasis Bahan Semikonduktor. Semin Nas Pendidik 2016. 2016;1(mV):730-42.

10. Kurnia M, Warsito A, Fisika J, Cendana UN. Perancangan Alat Pembuka dan Penutup Atap Penjemur Gabah Secara Otomatis dengan Menggunakan Arduino Uno Berbasis Mikrokontroler ATMega3218. 3.

11. Mufida E, Nurajizah S, Abas A. Pengendali Atap Jemuran Otomatis Dengan Sensor Cahaya Berbasiskan Mikrokontroler Atmega16. Informatics Educ Prof. 2017;1(2):163-72.

12. Jaelani I, Sompie ST., MT SRUA, Mamahit ST., M.Eng DJ. Rancang Bangun Rumah Pintar Otomatis Berbasis. E-Journal Tek Elektro dan Komput. 2016;5(1):1-10.

13. Punaji Setyosari. Punaji Setyosari. 2010.Metode Penelitian Pendidikan dan Pengembangan. Jakarta Kencana. 2010.

14. Haryati S. Research and Development (R\&D) Sebagai Salah Satu Model Penelitian dalam Bidang Pendidikan. Res Dev Sebagai Salah Satu Model Penelit Dalam Bid Pendidik. 2012;37(1):11-26.

15. Cates WM. Richey, Klein \& Tracy: The instructional design knowledge base: theory, research, and practice. Educ Technol Res Dev. 2011;59(5):737-9.

16. Sugiyono. Metode Penelitian dan Pengembangan (Research and Development/R\&D). Bandung Alf. 2016; 